\title{
Survey of helminth parasites of cats from the metropolitan area of Cuiabá, Mato Grosso, Brazil
}

\author{
Estudo da helmintofauna de gatos da região Metropolitana de Cuiabá, Mato Grosso, Brasil \\ Dirceu Guilherme de Souza Ramos ${ }^{1}$; Renatha Gabrielly Alves da Cruz Scheremeta ${ }^{2}$; \\ Anderson Castro Soares de Oliveira ${ }^{1}$; Afonso Lodovico Sinkoc ${ }^{1}$; Richard de Campos Pacheco ${ }^{1 *}$ \\ ${ }^{1}$ Programa de Pós-graduação em Ciências Veterinárias, Faculdade de Agronomia, Medicina Veterinária e Zootecnia, \\ Universidade Federal de Mato Grosso - UFMT, Cuiabá, MT, Brasil \\ ${ }^{2}$ Faculdade de Agronomia, Medicina Veterinária e Zootecnia, Universidade Federal de Mato Grosso - UFMT, Cuiabá, MT, Brasil
}

Received April 18, 2012

Accepted December 3, 2012

\begin{abstract}
Besides presenting zoonotic potential, helminths of cats are responsible for gastrointestinal, hepatic, and pulmonary diseases. In order to identify the helminthic fauna, prevalence, mean intensity of parasitism (MIP), and mean abundance population (MAP), 146 cats from the metropolitan area of Cuiabá, Midwestern Brazil, were necropsied. In 98 these animals, 12 species of helminths were identified, comprising (species, prevalence, MIP, and MAP, respectively): nematodes (Ancylostoma braziliense [50,68\% - 53,64 - 27,18], Ancylostoma tubaeforme [10,27\% - 3,6 - 0,37], Toxocara cati $[4,11 \%-28,33-1,16]$, Physaloptera praeputialis [2,05\% - 6,67 - 0,14], Capillaria feliscati $[3,42 \%-7,4-0,25]$, and Aelurostrongylus abstrusus [1,37\%]); cestodes (Spirometra mansonoides [4,11\% - 2,0 - 0,08], Dipylidium caninum $[3,42 \%-5,2-0,18]$, and Taenia taeniformis $[0,68 \%-1,0-0,01])$; trematodes (Platynosomum fastosum [26,03\% - 179,53 - 46,73]); acanthocephalans (Centrorhynchus erraticus [3,42\% - 3,2 - 0,11]). Ancylostoma spp., and P. fastosum were the most prevalent with the highest MIP and MAP. We observed the presence of species of helminths with zoonotic potential. This is the first time cats parasitized with Centrorhynchus erraticus are reported in the Americas. That genus is commonly observed in wild animals.
\end{abstract}

Keywords: Identification, quantification, parasitism, Centrorhynchus, zoonosis, prevalence.

\section{Resumo}

Helmintos de gatos são causadores de doenças gastrintestinais, hepáticas e pulmonares, além de apresentarem potencial zoonótico. Com objetivo de identificar a helmintofauna, prevalência, intensidade média de parasitismo (IMP) e abundância média populacional (AMP) foram necropsiados 146 gatos da região metropolitana de Cuiabá, centro-oeste do Brasil. Foram identificadas em 98 animais 12 espécies de helmintos compreendendo (respectivamente espécie, prevalência, IMP e AMP): nematódeos (Ancylostoma braziliense [50,68\% - 53,64 - 27,18], Ancylostoma tubaeforme [10,27\% - 3,6 - 0,37], Toxocara cati [4,11\% - 28,33 - 1,16], Physaloptera praeputialis [2,05\% - 6,67 - 0,14], Capillaria feliscati [3,42\% - 7,4-0,25] e Aelurostrongylus abstrusus [1,37\%]); cestódeos (Spirometra mansonoides [4,11\% - 2,0 - 0,08], Dipylidium caninum [3,42\% - 5,2 - 0,18] e Taenia taeniformis [0,68\% - 1,0-0,01]); trematódeos (Platynosomum fastosum [26,03\% - 179,53 - 46,73]); acantocéfalos (Centrorhynchus erraticus [3,42\% - 3,2 - 0,11]). Ancylostoma spp. e Platynosomum fastosum foram os mais prevalentes e com maior IMP e AMP. Esta é primeira descrição do gênero Centrorhynchus erraticus de gatos parasitados nas Américas.

Palavras-chave: Identificação, quantificação, parasitismo, Centrorhynchus, zoonoses, prevalência.

\footnotetext{
${ }^{*}$ Corresponding author: Richard de Campos Pacheco Departamento de Ciências Básicas e Produção Animal, Universidade Federal de Mato Grosso - UFMT,

Av. Fernando Corrêa da Costa, 2367, Boa Esperança, CEP 78060-900, Cuiabá, MT, Brasil

e-mail: richard@ufmt.br
} 


\section{Introduction}

Pets have socio-cultural importance and the pet-human interaction brings great benefits to human health, but also presents risks of diseases transmission (McNICHOLAS et al., 2005). The role of cats as hosts for endoparasitic infections that are potentially transmitted to humans has been recognized as a significant public health problem worldwide (SCHANTZ, 1994).

Parasites are among the most common causes of gastrointestinal disease in domestic cats (CALVETE et al., 1998), and some helminths present zoonotic potential: infection with migrating Toxocara spp. larvae has been associated with two main clinical syndromes in humans (ocular larva migrans and visceral larva migrans) (BOWMAN, 2010); and migration of Ancylostoma spp. larvae are responsible for a linear, tortuous, erythematous, and intensely pruritic eruption of the human skin called human cutaneous larva migrans (BOWMAN et al., 2010). Other organs such as the liver and lungs may also be affected by helminths, and despite not presenting zoonotic potential, they may be a frequent cause of risks to the health of their hosts, especially Platynosomum fastosum, which causes hepatic diseases in cats (FERREIRA et al., 1999; XAVIER et al., 2007), and Aelurostrongylus abstrusus, in cardiopulmonary cases (TRAVERSA et al., 2010). Despite the extensive parasitic fauna described in cats (BOWMAN et al., 2002), studies have shown, by examination of fecal samples or necropsies of cats, that parasitic fauna varies across geographical regions according to season, rural or urban areas, and other factors (CALVETE et al., 1998; LABARTHE et al., 2004; ABU-MADI et al., 2008; GATES; NOLAN, 2009).

The objective of this study was to collect, identify and calculate the mean intensity of parasitism (MIP) and mean abundance population (MAP) of the helminthes species found in cats from the metropolitan area of Cuiabá, State of Mato Grosso (MT), Midwestern of Brazil.

\section{Materials and Methods}

From August 2010 to June 2011, 146 cats (Felis silvestris catus) from the Zoonosis Control Center (CCZ) from the municipalities of Cuiabá and Várzea Grande, MT, Brazil were collected and necropsied. These animals were derived from capture in public areas and euthanized according to the protocol of the American Veterinary Medical Association (AVMA), Guidelines on Euthanasia (AVMA, 2001). As described by Sharif et al. (2007), based on dental development, maturation of genital structure and body size, the specimens were divided by sex and into adult $(1.5-3.0 \mathrm{~kg})$ and young $(\leq 1.4 \mathrm{~kg})$ age groups, and then necropsied (UENO; GONÇALVES, 2010). This study was approved by the Ethics Committee on Animal Research of the Federal University of Mato Grosso (Protocol No. 23108.027980/10-8). The sample size was performed using the prevalence of gastrointestinal helminth parasites detected in Rio de Janeiro (Brazil) by Labarthe et al. (2004) with 95\% confidence level and 5\% statistical error.

During the necropsy, the esophagus, stomach, small intestine and large intestine were individually washed and filtered in $0.15 \mathrm{~mm}$ sieve, and examined in stereomicroscope under 10x magnification.
The same procedure was used for the liver (gallbladder and bile ducts), pancreas, heart, kidneys, bladder and ureters. The lungs were opened by the bronchial tree for washing the content in the sieve, and later searched for parasites and/or injuries and, in these situations, fragments were subjected to histopathological examination stained by hematoxylin-eosin (BEHMER et al., 1976).

All the helminth parasites found were collected and processed according to Hoffman (1987). The identification was carried out following specific keys according to each taxonomic group: Anderson et al. (2009) and Gibbons (2010), for nematodes; Khalil et al. (1994), for cestodes; and Travassos et al. (1969) and Bray et al. (2008), for trematodes. For Capillaria spp., descriptions by Freitas and Lent (1936) and Moravec (1982) were used. For Centrorhynchus spp., descriptions by Chandler (1925), Kostylew (1926), and Yanchev and Genov (1979) were used.

Prevalence, MIP, and MAP were calculated according to Bush et al. (1997), using the software Quantitative Parasitology 3.0 (RÒSZA et al., 2000). Prevalence and intensity statistical analysis were performed using the methodology of generalized linear models (GLM) and the statistical package R (R DEVELOPMENT CORE TEAM, 2011) by comparing sex groups (male and female) and age (young and adult), as well as the interaction between them. For variable prevalence, a binomial distribution (presence or absence of the characteristic) was used, with the aid of the logistic link function as a linear predictor. For variable mean intensity, Poisson distribution (count of individuals) was used, with the logarithmic link function as a linear predictor.

\section{Results}

Of the 146 cats examined, 63 were males and 83 were females, 80 were young and 66 were adults. Overall, 98 (67.12\%) animals were parasitized with at least one species of the eleven detected: Ancylostoma braziliense Gomes de Faria, 1910; Ancylostoma tubaeforme (Zeder, 1800); Toxocara cati (Schrank, 1788) Brumpt, 1927; Physaloptera praeputialis Von Linstow, 1889; Aelurostrongylus abstrusus (Railliet, 1898) Cameron, 1927; Capillaria feliscati (Diesing, 1851) Travassos, 1915; Platynosomum fastosum (Braun, 1901) Kossack, 1910; Spirometra mansonoides Mueller, 1935; Dipylidium caninum (Linnaeus, 1758) Leuckart, 1863; Taenia taeniformis (Batsch, 1786) Wolffügel, 1911; and Centhorhynchus erraticus, Chandler, 1925, in a total of 11,129 helminths.

The most prevalent genus (Figure 1) was Ancylostoma spp. (60.96\%), with $50.68 \%$ species $A$. braziliense and $10.27 \%$ A. tubaeforme, infecting 89 animals, with MIP 45.20 (1-1433) and MAP 27.55. Among the groups, prevalence was higher in adults than in young animals $(\mathrm{P}<0.01)$, as shown in Figure 2 . There was no statistical difference between males and females. There was statistical interaction between age and sex to the mean intensity of parasitism that was higher in young males, followed by adult females, adult males, and young females $(\mathrm{P}<0.001)$ (Figure 3$)$.

Thirty-eight animals (26.03\%) were parasitized with $P$. fastosum showing MIP 179.53 (1-1093) and MAP 46.73. Prevalence was higher in adults than in young animals $(\mathrm{P}<0.001)$ (Figure 4$)$, with no statistically significant difference between males and females. The MIP also presented interaction between the groups, 


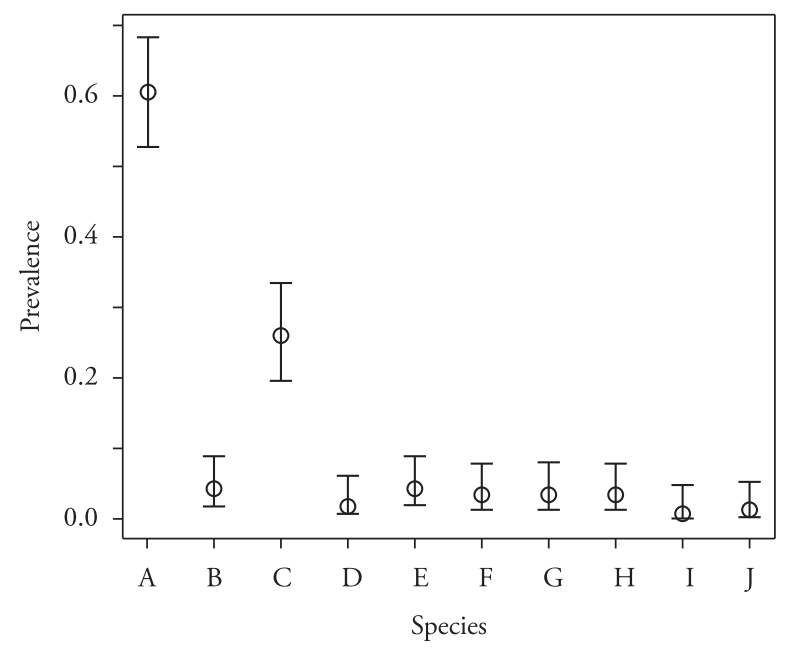

Figure 1. Prevalence of helminths in the metropolitan area of Cuiabá, MT, Brazil, from August 2010 to June 2011. p < 0.001. a) Ancylostoma spp.; b) Toxocara cati; c) Platynosomum fastosum; d) Physaloptera praeputialis; e) Spirometra mansonoides; f) Capillaria feliscati;g) Centrorhynchus erraticus; h) Dipylidium caninum; i) Taenia taeniformis; j) Aelurostrongylus abstrusus.

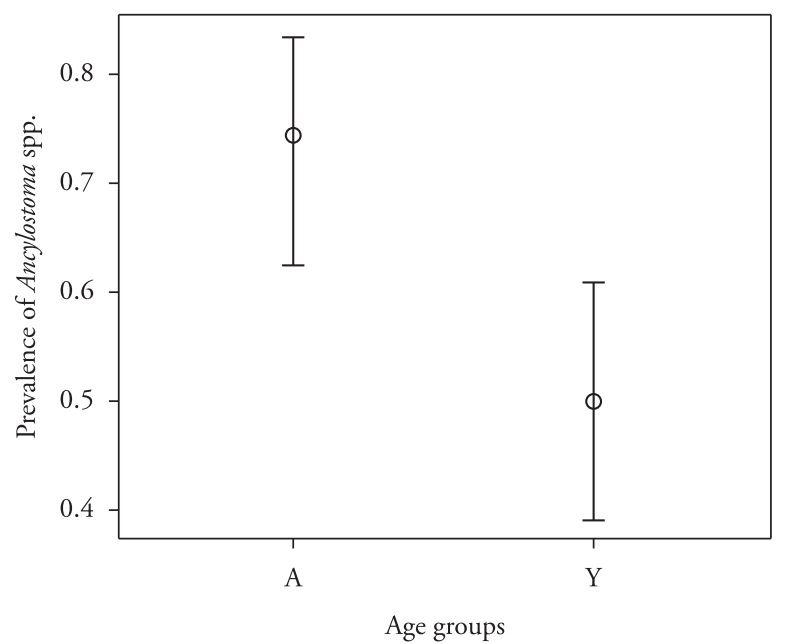

Figure 2. Prevalence of Ancylostoma spp. in cats according the age group in the metropolitan area of Cuiabá, MT, Brazil, from August 2010 to June 2011. p < 0.01. A- Adults; Y- Youngs.

where young females had higher MIP followed by adult females, adult males, and young males $(\mathrm{P}<0.001)$, as shown in Figure 5.

Two animals harbored $A$. abstrusus adults in the bronchial tree, as well as larvae and eggs that were observed in the histopathological examination of the lungs, which also showed inflammatory reaction in the alveoli and eosinophilic granulomas. Due to their small size, eggs in varied stages of development, and larvae found in nests in the lung parenchyma, the count of individuals was not feasible, so the MIP and MAP were not measured.

Five animals were infected by $C$. erraticus, an acanthocephalan found in the small intestine. The data for other species are presented in Table 1. Statistical comparisons by sex and age group of hosts were not possible for these species, since there were not enough repetitions for a reliable statistical analysis.

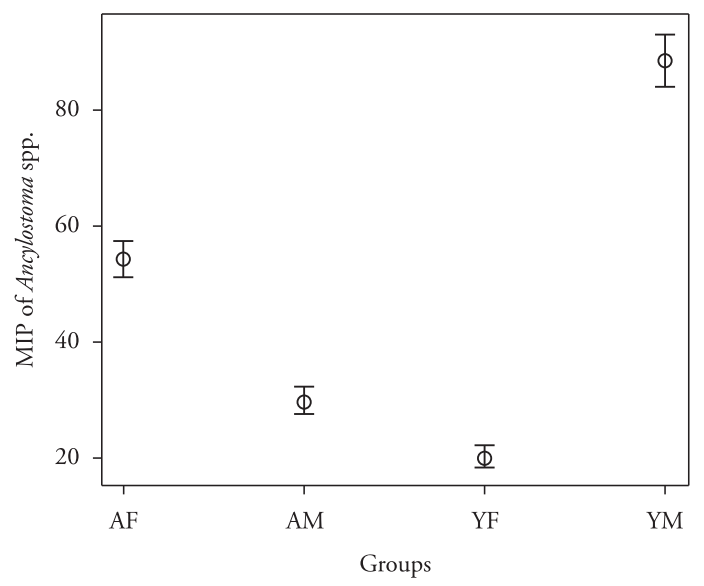

Figure 3. Mean Intensity of Parasitism (MIP) of Ancylostoma spp. in cats according sex and age with statistically interaction on groups of cats in the metropolitan area of Cuiabá, MT, Brazil, from August 2010 to June 2011. p < 0,001. AF- Adult females; AM- Adult males; YF- Young females; YM- Young males.

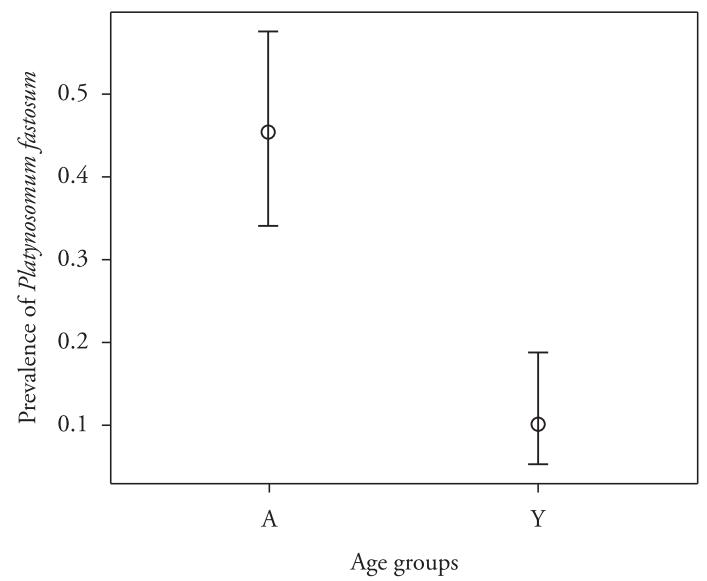

Figure 4. Prevalence of Platynosomum fastosum in cats according the age group in the metropolitan area of Cuiabá, MT, Brazil, from August 2010 to June 2011. $\mathrm{p}<0.001$. A- Adults; Y- Youngs.

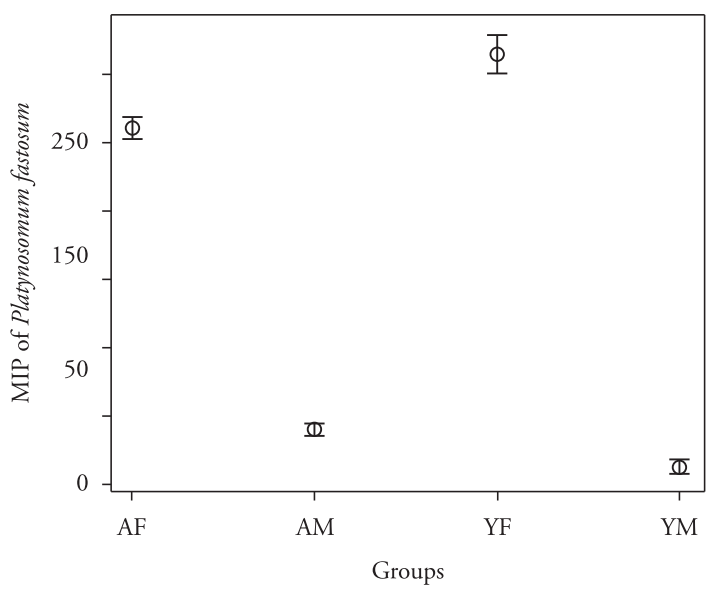

Figure 5. Mean Intensity of Parasitism (MIP) of Platynosomum fastosum. in cats according sex and age with statistically interaction on groups of cats in the metropolitan area of Cuiabá, MT, Brazil, from August 2010 to June 2011. p < 0,001. AF- Adult females; AM- Adult males; YF- Young females; YM- Young males. 
Table 1. Number of infected animals, prevalence, mean intensity and mean abundance of helminths analyzed in 146 cats in the metropolitan area of Cuiabá, MT, Brazil, from August 2010 to June 2011.

\begin{tabular}{|c|c|c|c|c|c|c|}
\hline \multirow{2}{*}{ Species } & \multirow{2}{*}{$\begin{array}{l}\text { Number of } \\
\text { infected cats }\end{array}$} & \multicolumn{3}{|c|}{ Prevalence $\%(p<0,001)$} & \multirow{2}{*}{ Mean Intensity } & \multirow{2}{*}{$\begin{array}{c}\text { Mean } \\
\text { Abundance }\end{array}$} \\
\hline & & Mean & Lower & Upper & & \\
\hline \multicolumn{7}{|l|}{ Nematoda } \\
\hline Ancylostoma spp. & 89 & 60,96 & 52,82 & 68,52 & 45,2 & 27,55 \\
\hline Toxocara cati & 6 & 4,11 & 1,85 & 8,84 & 28,33 & 1,16 \\
\hline Physaloptera praeputialis & 3 & 2,05 & 0,66 & 6,17 & 6,67 & 0,14 \\
\hline Capillaria feliscati & 5 & 3,42 & 1,43 & 7,96 & 7,4 & 0,25 \\
\hline Aelurostrongylus abstrusus* & 2 & 1,37 & 0,34 & 5,3 & - & - \\
\hline \multicolumn{7}{|l|}{ Trematoda } \\
\hline Platynosomum fastosum & 38 & 26,03 & 19,55 & 33,74 & 179,53 & 46,73 \\
\hline \multicolumn{7}{|l|}{ Cestoda } \\
\hline Spirometra mansonoides & 6 & 4,11 & 1,85 & 8,84 & 2 & 0,08 \\
\hline Dipylidium caninum & 5 & 3,42 & 1,43 & 7,96 & 5,2 & 0,18 \\
\hline Taenia taeniformis & 1 & 0,68 & 0,09 & 4,69 & 1 & 0,01 \\
\hline \multicolumn{7}{|l|}{ Acantocephala } \\
\hline Centrorhynchus erraticus & 5 & 3,42 & 1,43 & 7,96 & 3,2 & 0,11 \\
\hline
\end{tabular}

* There was no counting of individuals, and no measurement of parameters of mean intensity and mean abundance, unviable by histopathological.

\section{Discussion}

Similar prevalence of Ancylostoma spp. was reported by Labarthe et al. (2004). Other studies show prevalence rates between 8.8\% (SCHUSTER et al., 2009) and 29.3\% (CALVETE et al., 1998). Millán and Casanova (2009) found prevalence of $91.4 \%$ on the island of Majorca, Spain. The high prevalence is probably associated to the direct life cycle of this genus, absence of intermediate hosts, high biotic potential of the female (200-6000 eggs per day), and the ability of infective larvae promote active infection; moreover, these larvae develop better in tropical areas with sandy soils, where they can find temperatures between $25^{\circ} \mathrm{C}$ and $30{ }^{\circ} \mathrm{C}$ (BOWMAN et al., 2002). Despite males and females appeared to be equally susceptible to infection, adult animals presented higher rates of infection compared to young animals, although the immune system is completely mature in adults, while it is in formation in young animals (SCHULTZ et al., 2010). Adult animals may have a chronic (compensated) hookworm infection usually without signs, as well as older animals that are more weakened may show a secondary (decompensated) hookworm disease usually associated with malnutrition and immunosuppression (BOWMAN, 2010), which supports the presence of adult animals with high MIP, since most of them were stray animals, nutritionally debilitated and with no preventive anthelmintic treatment (unpublished data).

Bowman et al. (2002) and Sharif et al. (2007) described T. cati as one of the most common parasites of cats around the world, but its prevalence is not always high, ranging from $0.8 \%$ (ABU-MADI et al., 2008) to 55.2\% (CALVETE et al., 1998). Labarthe et al. (2004) using a methodology similar to the one described in this study, found prevalence of $25.2 \%$ for $T$. cati in Rio de Janeiro, Brazil. The prevalence found for T. cati in cats in the present study $(4.11 \%)$ is below the mean prevalence found in other studies. Woodruff et al. (1981) described desiccation and sunlight as factors that decrease the ability of infection of eggs larvae, and these two factors were clearly observed in the areas of this study, which suffers with low humidity, high temperatures and the occurrence of fires, common in the cerrado areas (data not show), especially during the dry season.

Companion animals, including cats, contribute significantly to contamination of the environment through their droppings, deposited in urban areas (ENGBAEK et al., 1984). The occurrence of the species described above, such as Ancylostoma spp. and Toxocara sp., which play an important role in public health, show the need to develop control programs aiming to decrease the occurrence of helminths in animals and possible exposure to these zoonotic agents to humans in public urban areas.

Labarthe et al. (2004) and Abu-Madi et al. (2008) presented similar prevalence levels to $P$. praeputialis. Infections by these worms are often associated with vomiting, and the adults are often viewed during endoscopy (BOWMAN, 2010). Labarthe et al. (2004) reported that its prevalence is probably underestimated, because the embryonated eggs are small, clear and colorless - they are often overlooked in fecal flotation. Except for intermittent vomiting in some infected cats, this parasite is relatively harmless.

Bowman et al. (2010) indicated that C. plica and C. feliscati could parasitize other parts of the bladder and lower urinary tract of cats, but the felines appeared to bear their usually modest worm burdens without inconvenience. Dantas et al. (2008) showed a clinical case of inferior urinary tract from a feline possibly caused by Capillaria spp., diagnosed by the presence of eggs in its urinalysis. In Brazil, this prevalence is possibly underestimated due to the low occurrence of clinical manifestations and also the methodology used for the analysis of parasite fauna, often focused on the fauna of the gastrointestinal tract (DANTAS et al., 2008).

$P$. fastosum parasites the bile and pancreatic ducts of cats, having a wide distribution in the Americas and also in Malaysia, 
Hawaii and West Africa (BOWMAN et al., 2002). In Brazil, Ferreira et al. (1999) showed prevalence of $37.2 \%$ in Rio de Janeiro, with sporadic cases of occurrence of the parasite associated with liver disorders (XAVIER et al., 2007; VIEIRA et al. 2009). Furthermore, it should be remembered by veterinarians as a differential diagnosis in cases of liver diseases.

As a common biological feature, all species of tapeworms detected ( $S$. mansonoides, $D$. caninum and $T$. taeniformis) require at least two hosts to complete their life cycle, where a suitable definitive host is infected through predation of the intermediate host. Thus, the presence of intermediate hosts is a determinant factor for the maintenance of the population of worms. Climatic and environmental factors can also be suggested to justify the low prevalence, since eggs are poorly resistant to high temperatures and low air relative humidity (CONBOY, 2009). Sparganosis is a parasitic infection caused by the plerocercoid larvae of the genus Spirometra, and humans are accidental hosts in their life cycle, while dogs, cats and other mammals are definitive hosts. Sparganosis in humans usually appears as subcutaneous nodules all over the body and can involve the eye, brain, and spinal cord, being characterized as an important zoonotic disease (CHUNG et al., 2012). So far, only four cases of sparganosis have been described in Brazil (states of Rio Grande do Sul, São Paulo and Santa Catarina) (MENTZ et al., 2011), which leads to believe in the risk of occurrence of this zoonosis in Midwestern Brazil.

Bowman et al. (2002) described three genera of acanthocephalans occurring in cats (Oncicola, Moniliformis and Centrorhynchus) as causes of intestinal disorders. The infection of cats by $C$. erraticus in this study, despite the low prevalence, reports for the first time its occurrence in cats in the Americas, described only by Chandler (1925) in Calcutta, India, probably as pseudoparasitism. The genus Centrorhynchus was termed by Van Cleave in 1916; presenting a broad variety of hosts like birds, wild mammals and reptiles (RICHARDSON; NICKOL, 1995). Another species of this genus, C. aluconis, was described in cats by Schuster et al. (2009) in Dubai, Kostylew (1926) in Russia, and Yanchev and Genov (1979) in Bulgaria. In Brazil, Stalliviere et al. (2009), through fecal examination, reported only the occurrence of acanthocephalans of the genus Oncicola in cats, with prevalence of $1.4 \%$ in Lages, State of Santa Catarina.

\section{Conclusion}

This study provides the occurrence of a broad parasitic fauna in cats (Physaloptera praeputialis, Aelurostrongylus abstrusus, Capillaria feliscati, Platynosomum fastosum, Dipylidium caninum, Taenia taeniformis) potentially pathogenic to these animals, as well as feline parasitic zoonoses, including the etiologic agents of clinical syndromes such as visceral and ocular larva migrans (Toxocara cati), cutaneous larva migrans (Ancylostoma braziliense and Ancylostoma tubaeforme) and sparganosis (Spirometra mansonoides). Furthermore, it describes for the first time the occurrence of Centrorhynchus erraticus in cats in South America, expanding the distribution of this acanthocephalan to the American continent.

\section{Acknowledgements}

The authors are grateful to CAPES for the scholarship granted to this study; PPGVET-UFMT, for the support for the development of this work; the Laboratory of Veterinary Pathology of HOVET-UFMT, for the assistance in the histopathological analysis; and the Zoonosis Control Centers of the municipalities of Cuiabá and Várzea Grande, for providing the samples.

\section{References}

Abu-Madi MA, Pal P, Al-Thani A, Lewis JW. Descriptive epidemiology of intestinal helminth parasites from stray cat populations in Qatar. $J$ Helminthol 2008; 82(1): 59-68. PMid:18199386. http://dx.doi. org/10.1017/S0022149X07870830

Anderson RC, Chabaud AG, Wilmott S. Keys to the Nematode Parasites of Vertebrates: Archival Volumes. Cambridge: Cabi; 2009.

American Veterinary Medical Association - AVMA. Report of the AVMA panel on Euthanasia. J Am Vet Med Assoc 2001; 218(5): 669-696. PMid:11280396. http://dx.doi.org/10.2460/javma.2001.218.669

Behmer OA, Tolosa EMC, Freitas-Neto AG. Manual de Técnicas para Histologia Normal e Patológica. São Paulo: Edart; 1976.

Bowman DD. Georgis - Parasitologia Veterinária. 9. ed. Rio de Janeiro: Elsevier; 2010.

Bowman DD, Hendrix CM, Lindsay DS, Barr SC. Feline Clinical Parasitology. Ames: Iowa State University Press; 2002. http://dx.doi. org/10.1002/9780470376805

Bowman DD, Montgomery SP, Zajac AM, Eberhard ML, Kazacos KR. Hookworms of dog and cats as agents of cutaneous larva migrans. Trends Parasitol 2010; 26(2): 162-167. PMid:20189454. http://dx.doi. org/10.1016/j.pt.2010.01.005

Bray RA, Gibson DI, Jones A. Keys to the Trematoda-3 vol. Cambridge: Cabi; 2008

Bush AO, Lafferty KD, Lotz JM, Shostak AW. Parasitology meets ecology on its own terms: Margolis et al. revisited. J Parasitol 1997; 83(4): 575-583. PMid:9267395. http://dx.doi.org/10.2307/3284227

Calvete C, Lucientes J, Castillo JA, Estrada R, Gracia MJ, Peribáñez $\mathrm{MA}$, et al. Gastrointestinal helminth parasites in stray cats from the mid-Ebro Valley, Spain. Vet Parasitol 1998; 75(2-3): 235-240. http:// dx.doi.org/10.1016/S0304-4017(97)00182-9

Chandler AC. The helminthic parasites of cats in Calcutta and the relation of cats to human helminthic infection. Indian J Med Res 1925; 13: 213 227.

Chung SW, Kim YH, Lee EJ, Kim DH, Kim GY. Two cases of pulmonary and pleural sparganosis confirmed by tissue biopsy and immunoserology. Braz J Infect Dis 2012; 16(2): 200-203. http://dx.doi.org/10.1016/ S1413-8670(12)70307-0

Conboy G. Cestodes of dogs and cats in North America. Vet Clin North Am Small Anim Pract 2009; 39(6): 1075-1090. PMid:19932364. http:// dx.doi.org/10.1016/j.cvsm.2009.06.005

Dantas DASB, Rodrigues MC, Sousa AF, Portela ACM, Oliveira WA. Infecção do trato urinário de um gato doméstico por Capillaria sp.: relato de caso. Clin Vet 2008; 76: 90-92. 
Engbaek K, Madsen H, Larsen SO. A survey of helminths in stray cats from Copenhagen with ecological aspects. $Z$ Parasitenkd 1984; 70(1): 87-94. PMid:6538054. http://dx.doi.org/10.1007/BF00929578

Ferreira AMR, Almeida ECP, Labarthe NV. Liver fluke infection (Platynosomum concinnum) in Brazilian cats: prevalence and pathology. Feline Pract 1999; 27(2): 19-22.

Freitas JFT, Lent H. Estudo sobre os Capillariinae parasitos de mammíferos (Nematoda: Trichuroidea). Mem Inst Oswaldo Cruz 1936; 31(1): 85-160.

Gates MC, Nolan TJ. Endoparasite prevalence and recurrence across different age groups of dogs and cats. Vet Parasitol 2009; 166(1-2): 153-158. PMid:19709815 PMCid:2783654. http://dx.doi.org/10.1016/j. vetpar.2009.07.041

Gibbons LM. Keys to the Nematode Parasites of Vertebrates: Supplementary Volume. Cambridge: Cabi; 2010.

Hoffman RP. Diagnóstico de parasitismo veterinário. Porto Alegre: Sulina; 1987.

Khalil LF, Jones A, Bray RA. Keys to the Cestode Parasite of Vertebrates. Cambridge: Cabi; 1994.

Kostylew N. Acanthocephalen der Hauskatze. ZoolAnz 1926; 68: 263-269.

Labarthe NV, Serrão ML, Ferreira AMR, Almeida NKO, Guerrero J. A survey of gastrointestinal helminths in cats of the metropolitan region of Rio de Janeiro, Brazil. Vet Parasitol 2004; 123(1-2): 133-139. PMid:15265577. http://dx.doi.org/10.1016/j.vetpar.2004.06.002

McNicholas J, Gilbey A, Rennie A, Ahmedzai S, Dono JA, Ormerod E. Pet ownership and human health: a brief review of evidence and issues. BMJ 2005; 331(7527): 1252-1254. PMid:16308387 PMCid:1289326. http://dx.doi.org/10.1136/bmj.331.7527.1252

Mentz MB, Procianoy F, Maestri MK, Rott MB. Case report human ocular sparganosis in southern Brazil. Rev Inst Med Trop S Paulo 2011; 53(1): 51-53. PMid:21412620. http://dx.doi.org/10.1590/ S0036-46652011000100009

Millán J, Casanova JC. High prevalence of helminth parasites in feral cats in Majorca Island (Spain). Parasitol Res 2009; 106(1): 183-188. PMid:19841943. http://dx.doi.org/10.1007/s00436-009-1647-y

Moravec F. Proposal of a new systematic arrangement of nematodes of de family Capilariidae. Folia Parasitol (PRAHA) 1982; 29(2): 119-132.

R Development Core Team. $R$ : A language and environment for statistical computing, reference index version 2.14.0. Vienna: R Foundation for Statistical Computing; 2011. Available from: http://www.R-project.org.

Richardson DJ, Nickol BB. The genus Centrorhynchus (Acantocephala) in North America with description of Centrorhynchus robustus n. sp., redescription of Centrorhynchus conspectus, and a key to species. J Parasitol 1995; 81(5): 767-772. PMid:7472871. http://dx.doi. org/10.2307/3283971
Ròsza L, Reiczigel J, Majoros G. Quantifying parasites in samples of hosts. J Parasitol 2000; 86(2): 228-232.

Schantz PM. Of worms, dogs and human hosts: continuing challenges for veterinarians in prevention of human disease. J Am Vet Med Assoc 1994; 204(7): 1023-1028. PMid:8045801.

Schultz RD, Thiel B, Mukhtar E, Sharp P, Larson LJ. Age and long-term protective immunity in dogs and cats. J Comp Pathol 2010; 142(S1): 102-108. PMid:19959181. http://dx.doi. org/10.1016/j.jcpa.2009.10.009

Schuster RK, Thomas K, Sivakumar S, O'Donovan D. The parasite fauna of stray domestic cats (Felis catus) in Dubai, United Arab Emirates. Parasitol Res 2009; 105(1): 125-134. PMid:19238440. http://dx.doi. org/10.1007/s00436-009-1372-6

Sharif M, Nasrolahei M, Ziapour SP, Gholami S, Ziaei H, Daryani A, Khalilian A. Toxocara cati infections in stray cats in northern Iran. J Helminthol 2007; 81(1): 63-66. PMid:17381869. http://dx.doi. org/10.1017/S0022149X07214117

Stalliviere FM, Bellato V, Souza AP, Sartor AA, Moura AB, Rosa LD. Ectoparasitos e helmintos intestinais em Felis catus domesticus, da cidade de Lages, SC, Brasil e aspectos sócio-econômicos e culturais das famílias dos proprietários dos animais. Rev Bras Parasitol Vet 2009; 18(4): 26-31. PMid:20040205. http://dx.doi.org/10.4322/rbpv.01804005

Travassos L, Freitas JFT, Kohn A. Trematódeos do Brasil. Mem Inst Oswaldo Cruz 1969; 67(1): 1-886. PMid:5397756.

Traversa D, Di Cesare A, Conboy G. Canine and feline cardiopulmonary parasitic nematodes in Europe: emerging and underestimated. Parasit Vectors 2010; 3: 1-22. PMid:20653938 PMCid:2923136. http://dx.doi. org/10.1186/1756-3305-3-62

Ueno H, Gonçalves PC. Manual para diagnóstico das helmintoses de ruminantes. Tokyo: Japan International Cooperation Agency; 2010. v. 3 , p. $80-82$.

Vieira ALS, Ecco R, Lima WS, Guedes RMC. Platynosomum fastosum infection in two cats in Belo Horizonte, Minas Gerais State - Brazil. Braz J Vet Pathol 2009; 2(1): 45-48.

Woodruff AW, Salih SY, Savigny D, Baya EI, Shah AI, Defalla AA. Toxocariasis in the Sudan. Ann Trop Med Parasitol 1981; 75(5): 559-561. PMid:7316582.

Xavier FG, Morato GS, Righi DA, Maiorka PC, Spinosa HS. Cystic liver disease related to high Platynosomum fastosum infection in a domestic cat. J Feline Med Surg 2007; 9(1): 51-55. PMid:17241806. http://dx.doi. org/10.1016/j.jfms.2006.08.006

Yanchev Y, Genov T. Helminthofauna of the wild cat (Felis silvestris Schreb.) in Bulgaria. Chelmitologija 1979; 6: 81-101. 